\title{
PENGARUH PROJECT BASED LEARNING DALAM MENINGKATKAN PRESTASI BELAJAR DAN KARAKTER SISWA PADA MATERI LARUTAN DENGAN SARANA LESSON STUDY
}

\section{The Effect of Project Based Learning in Improving Student Achievement and Character in Solution Materials with Lesson Study Facilities}

\author{
Lily Budinurani \\ Prodi Teknik Otomotif Politeknik Baja Tegal, Tegal \\ *email: lilybudinurani@gmail.com
}

\begin{abstract}
Abstrak. Salah satu pembelajaran yang dapat membangkitkan aktivitas dan kemandirian siswa adalah project based learning. Penelitian ini bertujuan untuk mengetahui pengaruh lesson study dalam meningkatkan capaian hasil belajar dan karakter siswa pada materi larutan dengan menggunakan metode project based learning. Jenis penelitian adalah eksperimen dengan desain posttest-only control design. Sampel yang digunakan siswa kelas X TKR SMK Bhakti Praja Dukuhwaru. Pengambilan sampel menggunakan teknik random sampling. Variabel bebas penelitian yaitu tingkat keterlaksanaan project based learning sedangkan variabel terikatnya adalah hasil belajar dan karakter siswa. Hasil uji perbedaan rata-rata nilai post-test menunjukkan bahwa rata-rata nilai post-test kelas eksperimen lebih baik dibandingkan dengan kelas kontrol. Rata-rata nilai akhir siswa kelas eksperimen lebih tinggi daripada kelas kontrol yakni kelas eksperimen sebesar 80 dan ketuntasan belajar mencapai $90 \%$ sedangkan kelas kontrol rata-rata nilai akhirnya sebesar 78 dan ketuntasan belajarnya hanya $86 \%$. Hasil uji $N$-Gain menunjukkan terdapat peningkatan antara sebelum diberikan perlakuan (pre-test) dengan sesudah diberikan perlakuan (post-test) yakni kelas yang menggunakan pembelajaran proyek rata-rata peningkatannya sebesar 0,72 pada kriteria tinggi sedangkan pada kelas kontrol hanya 0,69 pada kriteria sedang. Berdasarkan hasil tersebut dapat disimpulkan bahwa project based learning berpengaruh positif terhadap peningkatan prestasi belajar siswa pada materi larutan yang dikemas dengan sarana lesson study dan mendapatkan respon positif dari siswa.
\end{abstract}

Kata kunci: project based learning, lesson study, prestasi belajar, karakter siswa

Abstract. One of the learning methods that can evoke student activity and independence is project based learning. This study aimed to determine the effect of lesson study on the learning outcomes and students' characters on solution material by using project based learning method. The type of this research was experiment with posttest-only control design. Students of class X in TKR SMK Bhakti Praja Dukuhwaru were the samples in this research. Random sampling technique was used for choosing sample. The independent variable of research was the level of implementation of project based learning, while the dependent variable was students' learning achievement and their characters. The result of the difference test of post-test score average showed that the average post-test 
score of the experimental class was better than the control class. The average final score of the experimental class was higher than the control which was 80 and the learning completeness reached $90 \%$, while the average final score of the control class was 78 and the learning completeness was only $86 \%$. The result of $N$-Gain test showed that there was an improvement of the score from before treatment (pre-test) to after treatment (post-test) in which the class that used the project based learning gained improvement of 0.72 on the high criteria, while the control class only gained 0.69 on medium criteria. Based on the result, it can be concluded that project based learning in lesson study had an effect on students' learning achievement and their characters on the topic of solution and got positive response from students.

Keywords: project based learning, lesson study, learning achievement, student

$$
\text { character }
$$

\section{PENDAHULUAN}

Istilah lesson study dalam pembelajaran di lingkungan SMK Bhakti Praja Dukuhwaru masih begitu asing bahkan belum pernah diterapkan dalam pembelajaran. Hal ini disebabkan karena harus melibatkan banyak pihak (terutama guru) sementara masing-masing guru memiliki tugas untuk mengajar di kelas-kelas yang berbeda sehingga kesulitan dalam menentukan waktu. Namun demikian sekolah selalu melaksanakan Inhouse Training (IHT) setiap awal tahun pembelajaran, sehingga tetap terjalin koordinasi antara guru mata pelajaran dalam mempersiapkan perangkat pembelajaran yang akan dilaksanakan setiap tahunnya.

Metode pembelajaran dalam kegiatan belajar mengajar merupakan salah satu faktor yang dapat menentukan hasil belajar. Sanjaya (2013) menyimpulkan "tidaklah lengkap manakala dalam stategi pembelajaran tidak membahas strategi pembelajaran yang berhubungan dengan pembentukan sikap dan karakter". Semakin tepat guru memilih pendekatan pembelajaran diharapkan semakin efektif pula dalam pembelajaran dan membuat siswa semakin mudah memahami materi pelajaran yang diajarkan. Jika pemahaman siswa terhadap materi pelajaran semakin baik maka akan berpengaruh pada hasil belajar siswa. Selain itu siswa SMK dipersiapkan untuk memasuki dunia kerja sehingga selain dituntut untuk meningkatkan potensi mereka juga dilatih untuk selalu siap siap dan bisa mandiri. Metode pembelajaran yang dapat mendukung siswa menjadi aktif, kreatif, tanggung jawab dan mandiri salah satunya adalah project based learning. Pada project based learning ini siswa dilatih untuk bertanggung jawab terhadap proyek yang sudah diberikan.

Berangkat dari ketertarikan peneliti terhadap kelanjutan dari pelaksanaan inhouse training di SMK Bhakti Praja Dukuhwaru dan ketertarikan peneliti untuk meningkatkan aktivitas dan kemandirian siswa, maka peneliti melaksanakan pembelajaran dengan menggunakan project based learning yang dikemas dengan sarana lesson study sebagai bentuk koordinasi persiapan pembelajaran yang lebih dalam lagi dari IHT untuk mata pelajaran kimia khususnya pada materi larutan serta untuk meningkatkan aktivitas belajar siswa. Penelitian bertujuan untuk mengetahui pengaruh project based learning terhadap prestasi belajar siswa yang dilakukan dengan menggunakan sarana lesson study 
sekaligus untuk mengetahui respon siswa terhadap pembelajaran project based learning pada materi larutan.

\section{METODE PENELITIAN}

Penelitian dilakukan di SMK Bhakti Praja Dukuhwaru Kabupaten Tegal pada materi pokok larutan. Penelitian dilaksanakan sesuai dengan tahapan pada lesson study yang meliputi tahap perencanaan (plan), pelaksanaan (do), dan refleksi (see) (Daryanto \& Arisandi, 2015). Pelaksanaan tahapan Plan, Do dan See ditampilkan pada Tabel 1.

Dalam penelitian ini peneliti menggunakan strategi metode campuran (mix method). Disini peneliti menggabungkan metode observasi dan wawancara (data kualitatif) dengan metode survei tradisional (data kualitatif) (Creswell, 2014). Penelitian merupakan jenis true experimental dengan posttest-only control design. Populasi penelitian siswa kelas X jurusan TKR tahun pelajaran 2019/2020. Pengambilan sampel dilakukan dengan teknik random sampling.

Tabel 1. Pelaksanaan tahapan lesson study

\begin{tabular}{cccc}
\hline No & Plan & Do & See \\
\hline 1. & 14 September 2019 & 28 Juli 2019 & 25 November 2019 \\
2. & 21 September 2019 & 4 Oktober 2019 & 1 Desember 2019 \\
3. & 28 September 2019 & 11 Oktober 2019 & - \\
4. & - & 18 Oktober 2019 & - \\
5. & - & 25 Oktober 2019 & - \\
\hline
\end{tabular}

Variabel bebas penelitian adalah model pembelajaran. Variasi perlakuan penggunaan project based learning pada kelas eksperimen dan metode konvensional pada kelas kontrol. Variabel terikat penelitian adalah prestasi belajar dan karakter siswa. Variabel kontrol penelitian adalah materi pelajaran, kurikulum, jumlah jam pelajaran, lesson study, guru pengajar dan soal pre test-post test.

Metode pengumpulan data dilakukan dengan metode dokumentasi, metode tes, metode observasi dan metode angket. Jenis data, instrumen dan teknik pengumpulan data dalam penelitian ini dirangkum dalam Tabel 2.

Tabel 2. Jenis data, instrumen, dan teknik pengumpulan data

\begin{tabular}{ccc}
\hline Jenis & Instrumen & Teknik Pengumpulan Data \\
\hline Validitas perangkat & Lembar validasi & Angket validasi \\
Hasil Belajar Kognitif & Butir soal tes & Tes \\
Karakter siswa & Lembar observasi & Observasi \\
Respon siswa terhadap & Lembar angket & Angket respon pembelajaran \\
pembelajaran & & untuk siswa \\
\hline
\end{tabular}

Hasil observasi karakter siswa selama proses pembelajaran dianalisis secara deskriptif dengan melihat hasil masing-masing aspek indikator. Adapun indikator dari karakter yang dikembangkan dapat dilihat pada Tabel 3. 
Tabel 3. Karakter yang dikembangkan Nilai Karakter

1. Menghargai dan menghayati ajaran agama yang dianut

2. Kreativitas

3. Kerjasama

4. Tanggung Jawab

5. Jujur

6. Disiplin

7. Santun

8. Percaya Diri

9. Kreativitas

Sugiyono (2015) menyimpulkan bahwa "analisis data dalam penelitian kualitatif dilakukan sejak sebelum memasuiki lapangan, selama di lapangan, dan setelah selesai di lapangan". Data yang diperoleh dari tes hasil belajar yang diberikan sebelum dan sesudah pembelajaran dianalisis dengan menggunakan rumus gain rata-rata ternormalisasi. Uji kelayakan dilakukan pada saat uji coba kelas terbatas. Uji efektivitas dilakukan pada saat uji coba lapangan. Perangkat pembelajaran dikatakan efektif jika dapat memberikan dampak positif terhadap pembelajaran. Adapun kriteria efektif dalam penelitian ini adalah adanya peningkatan capaian hasil belajar, karakter siswa memenuhi kriteria tinggi, rata-rata hasil belajar siswa mencapai kriteria ketuntasan minimal yang ditetapkan yaitu 75 secara klasikal dan minimal $75 \%$ siswa memberikan respon positif terhadap project based learning yang dilaksanakan.

\section{HASIL DAN PEMBAHASAN}

Pemahaman materi pelajaran yang benar, penerapan pedagogi yang tepat dan kecekatan menyiasati kekurangan fasilitas pembelajaran akan menjadikan pembelajaran lebih efektif dan efisien. Dalam lesson study guru memperoleh kesempatan untuk melakukan identifikasi masalah pembelajaran, mengkaji pengalaman yang bisa dilakukan, memilih alternatif model pembelajaran yang akan digunakan, merancang rencana pembelajaran, mengkaji kelebihan dan kekurangan alternatif model pembelajaran yang dipilih. Daryanto \& Arisandi (2015) menyatakan bahwa "lesson study dilaksanakan dalam tiga tahapan yaitu Plan (merencanakan), Do (melaksanakan), dan See (refleksi) yang berkelanjutan. Dengan kata lain lesson study merupakan suatu cara peningkatan mutu pendidikan yang tak pernah berakhir (continous improvement)". Skema lesson study diperlihatkan pada Gambar 1.

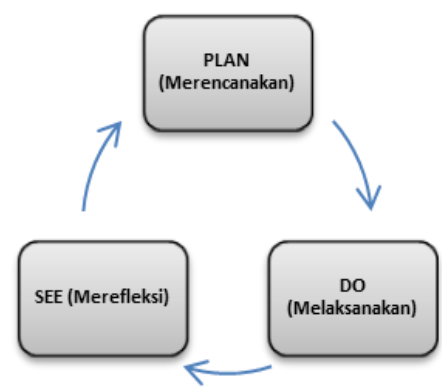

Gambar 1. Siklus lesson study 


\section{Tahap Perencanaan (Plan)}

Tahap perencanaan (plan) merupakan awal dari tahapan Lesson study. Perencanaan yang baik tidak dilakukan sendirian tetapi dilakukan bersama, beberapa guru dapat berkolaborasi untuk memperkaya ide (Daryanto \& Arisandi, 2015). Studi pendahuluan yang telah dilaksanakan menghasilkan kesepahaman mengenai rencana pembelajaran yang akan diterapkan yaitu untuk meningkatkan penguasaan kognitif dan karakter siswa. Langkah selanjutnya bersama dengan guru kolaborasi melakukan diskusi tentang pokok-pokok yang harus dilakukan dalam menyusun rancangan materi pembelajaran dan instrumen-instrumen yang diperlukan dalam pembelajaran.

Beberapa aktivitas yang dilakukan saat tahap perencanaan bersama dengan tim lesson study diantaranya merancang instrumen pembelajaran yang akan digunakan meliputi pengembangan silabus, RPP, instrumen penilaian, lembar kerja siswa termasuk memberikan masukan-masukan terhadap bahan ajar yang akan digunakan.

\section{Tahap Pelaksanaan (Do)}

Tahap pelaksanaan (Do) bertujuan untuk mengujicoba efektivitas metode pembelajaran yang telah dirancang (Daryanto \& Arisandi, 2015). Pada tahap pelaksanaannya, guru yang telah ditunjuk dan disepakati oleh kelompok lesson study melakukan implementasi semua rencana dari hasil diskusi tahap perencanaan sebelumnya pada kelas kontrol dan kelas eksperimen. Pakar dan guru lain melakukan observasi dengan menggunakan lembar observasi yang telah dipersiapkan dan perangkat lain yang diperlukan. Para observer mencatat hal-hal positif maupun negatif dalam proses pembelajaran, terutama dilihat dari tingkah laku siswa. Para observer fokus terhadap aktivitas siswa, bukan guru. Dengan mengetahui bagaimana aktivitas siswa maka observer bisa memberikan saran/masukan kepada guru untuk perbaikan proses pembelajaran pada pertemuan berikutnya.

Awal pelaksanaan pembelajaran di kelas eksperimen siswa cenderung canggung dengan metode pembelajaran yang diberikan. Hal ini dikarenakan setiap siswa merasa setiap aktivitas diamati oleh observer. Namun pada pertemuan berikutnya siswa tampak menikmati kondisi pembelajaran, dan dapat melaksanakan tugas-tugas yang diberikan dengan baik. Guru model berusaha membuat siswa aktif mengikuti proses pembelajaran. Guru model juga memberikan kesempatan kepada siswa untuk bertanya, dan menjawab pertanyaan.

Pada saat pembelajaran peneliti juga mengamati guru model apakah telah menjalankan RPP, metode dan media pembelajaran yang telah dibuat pada tahap perencanaan (plan). Peneliti juga mengamati observer lain apakah telah melaksanakan fungsinya dengan melakukan observasi pada saat proses pembelajaran dilaksanakan oleh guru model.

Keadaan ketika siswa merasa jenuh teramati oleh observer yaitu ketika jam pelajaran sudah terlampau lama, observer ketika refleksi memberikan masukan untuk menampilkan video yang berkaitan dengan proyek yang akan ditugaskan dengan siswa yang sudah dicantumkan dalam bahan ajar, minimal agar siswa memiliki gambaran bagaimana yang harus mereka lakukan kelak untuk menyelesaikan tugas proyeknya.

Pelaksanaan lesson study dalam pembelajaran memberikan dampak positif terhadap siswa dan guru. Hal ini karena pada pelaksanaannya peserta lesson study melakukan kegiatan-kegiatan yang dapat meningkatkan kompetensi keprofesionalannya 
mulai dari menentukan cakupan materi yang akan diajarkan, membuat RPP, menentukan media pembelajaran, menentukan metode pembelajaran, membuat instrumen penilaian siswa, melakukan proses pembelajaran, memberi masukan kepada sesama peserta lesson study dan juga menerima masukan dari sesama peserta lesson study. Hal ini sesuai dengan pendapat yang dikemukakan oleh Kellough (dalam Danim 2010:57) bahwa seorang guru yang profesional harus memiliki kompetensi diantaranya guru harus menguasai pengetahuan tentang materi pelajaran yang diajarkannya, guru merupakan anggota aktif organisasi profesi guru, membaca jurnal profesional, melakukan dialog dengan sesama guru, mengembangkan kemahiran metodologi, membina siswa dan materi pelajaran, guru harus memperlihatkan perhatian terus menerus dalam tanggung jawab profesional dalam setiap kesempatan, dan lain-lain. Dampak lain yang muncul dari kualitas pembelajaran guru yang semakin kaya akan wawasan inipun akhirnya berimbas pada siswa, dimana pembelajaran menjadi lebih menyenangkan, kekurangan siswa selalu dapat diatasi dan kebutuhan siswa selalu dapat dipenuhi. Dari hal ini akhirnya menjadikan pembelajaran lebih berkualitas dan daya tengkap siswa lebih tinggi dan capaian hasil belajar dapat meningkat.

Analisis data pre test dan post test diperoleh rata-rata nilai pre test siswa kelas sampel yang tidak berbeda signifikan. Hal ini menunjukkan sampel berangkat dari keadaan yang sama. Analisis data akhir post test siswa pada masing-masing kelas menunjukkan adanya perbedaan. Rata-rata hasil belajar siswa kelas eksperimen lebih tinggi dibandingkan rata-rata hasil belajar kelas kontrol. Data rata-rata pre test dan post test dapat dilihat pada tabel 4.

Tabel 4. Rata-rata pretest dan posttest

\begin{tabular}{|c|c|c|c|}
\hline \multirow{2}{*}{ Kelas } & \multirow{2}{*}{$\mathbf{N}$} & \multicolumn{2}{|c|}{ Rata-rata } \\
\hline & & Pretest & Post test \\
\hline Eksperimen & 30 & 31 & 80 \\
\hline Kontrol & 30 & 30 & 78 \\
\hline
\end{tabular}

Berdasarkan analisis uji Chi Kuadrat yang dilakukan terhadap post test kelas eksperimen menghasilkan $\mathrm{X}^{2}$ hitung sebesar 552,89 sedangkan untuk $\mathrm{X}_{\text {tabel }}^{2}$ dengan taraf nyata $(\alpha)=0,01$ dan $n=30$ diperoleh nilai 11,3 Hasil uji Chi Kuadrat terhadap post test menunjukkan bahwa $\mathrm{X}_{\text {hitung }}^{2}>\mathrm{X}_{\text {tabel }}^{2}$. Hasil post test yang dihasilkan dari kelas eksperimen tidak berdistribusi normal. Uji Chi Kuadrat yang dilakukan terhadap post test kelas kontrol menghasilkan $\mathrm{X}^{2}$ hitung sebesar 30,367 sedangkan untuk $\mathrm{X}_{\text {tabel }}^{2}$ dengan taraf nyata $(\alpha)=0,01$ dan $n=30$ diperoleh nilai 11,3 Hasil uji Chi Kuadrat terhadap post test menunjukkan bahwa $\mathrm{X}_{\text {hitung }}^{2}>\mathrm{X}_{\text {tabel. }}^{2}$. Hal ini dapat diartikan data post test yang dihasilkan dari kelas kontrol juga tidak berdistribusi normal.

Suatu variansi data dapat dikatakan homogen jika $\mathrm{F}_{\text {hitung }}<\mathrm{F}_{\text {tabel. }}$. Menurut Sugiyono (2014:141), "Apabila harga $F_{\text {hitung }}$ lebih kecil atau sama dengan $F_{\text {tabel }}$ pada taraf signifikansi 5\% ( $\alpha=0,05 \%$ dengan dk pembilang $\left(\mathrm{dk}_{1}=\mathrm{n}_{1}-1\right)$ dan dk penyebut $\left(\mathrm{dk}_{2}=\mathrm{n}_{2^{-}}\right.$ 1), maka $\mathrm{H}_{0}$ diterima, artinya kedua data memliki varians yang sama, dan apabila harga $\mathrm{F}_{\text {hitung }}$ lebih besar dengan $\mathrm{F}_{\text {tabel }}$ maka $\mathrm{H}_{0}$ ditolak". Dari hasil penghitungan uji homogenitas variansi data pre test dan post test diperoleh $\mathrm{F}_{\text {hitung }}$ sebesar 1,079 dan $\mathrm{F}_{\text {tabel }}$ dengan dk pembilang dan penyebut masing-masing n-1 (30-1=29) sebesar 1,85. Hasil tersebut menunjukkan bahwa variansi data pre test dan post test terbukti homogen. 
Dari uji normalitas dan homogenitas seluruh data, dihasilkan bahwa data pre test kelas kontrol maupun kelas eksperimen keduanya berdistribusi normal dan homogen. Namun data post test yang dihasilkan tidak berdistribusi normal, oleh karena itu pemilihan uji statistik yang digunakan adalah uji nonparametrik. Uji tersebut menggunakan uji perbandingan yang dilakukan dengan menggunakan uji Wilcoxon dengan kriteria pengujian; (1) $\mathrm{H}_{0}: \mu_{\mathrm{x}}=\mu_{\mathrm{y}}$ yang artinya tidak terdapat perbedaan hasil belajar antara siswa kelas kontrol dengan kelas eksperimen, dan (2) Ha $: \mu_{\mathrm{x}} \neq \mu_{\mathrm{y}}$ yang artinya terdapat perbedaan hasil belajar antara siswa kelas kontrol dengan kelas eksperimen. Uji hipotesis ini dilakukan dengan dua arah, dengan tingkat kepercayaan $95 \%$ maka nilai kritis $Z$ dengan uji 2 arah setengah dari $\alpha 0,05$ yaitu 0,025 , sehingga luas kurva adalah 0,475 sehingga luas kurva 0,475 dengan mencari pada nilai tabel $\mathrm{Z}$ didapatkan nilai $Z_{\text {tabel }} \pm 1,96$. Nilai $Z$ yang dihasilkan pada uji Wilcoxon sebesar $-4,64$, sehingga nilai $\mathrm{Z}$ berada di daerah penolakan $\mathrm{H}_{0}$ dan penerimaan $\mathrm{H}_{1}$. Dengan demikian dapat disimpulkan bahwa terdapat perbedaan hasil belajar antara siswa kelas eksperimen dengan siswa kelas kontrol. Secara umum hasil penguasaan konsep siswa mengalami peningkatan dengan pembelajaran proyek. Penguasaan konsep sebagai aspek kognitif mengalami perubahan akibat pelaksanaan pembelajaran proyek. Pembelajaran yang dilaksanakan mampu mengoptimalkan kompetensi siswa sehingga lebih paham dan menguasai materi. Rekapitulasi hasil pre test dan post test penguasaan konsep disajikan pada Tabel 5 dan 6 .

Tabel 5. Rekapitulasi hasil pre test dan post test penguasaan konsep kelas kontrol

\begin{tabular}{clcc}
\hline No & \multicolumn{1}{c}{ Aspek } & Pre Test & Post Test \\
\hline 1. & Jumlah siswa & 30 & 30 \\
2. & Rata-rata & 30 & 78 \\
3. & Nilai tertinggi & 51 & 94 \\
4. & Nilai terendah & 11 & 57 \\
5. & Jumlah siswa yang tuntas belajar & - & 26 \\
\hline
\end{tabular}

Tabel 6. Rekapitulasi hasil pre test dan post test penguasaan konsep kelas eksperimen

\begin{tabular}{clcc}
\hline No & \multicolumn{1}{c}{ Aspek } & Pre test & Post test \\
\hline 1. & Jumlah siswa & 30 & 30 \\
2. & Rata-rata & 31 & 80 \\
3. & Nilai tertinggi & 46 & 97 \\
4. & Nilai terendah & 14 & 60 \\
5. & Jumlah siswa yang tuntas belajar & - & 27 \\
\hline
\end{tabular}

Pada hasil pre-test tidak ada siswa yang tuntas belajar. Setelah diberikan perlakuan dengan menggunakan pembelajaran berbasis proyek ketuntasan mengalami peningkatan. Perlakuan pada kelas kontrol dari 30 siswa sebanyak 26 siswa mendapat nilai tuntas dan yang belum tuntas 4 siswa sedangkan pada kelas eksperimen dari 30 siswa, 27 diantaranya mendapatkan nilai tuntas dan 3 diantaranya belum tuntas. Berdasarkan analisis statistik, diperoleh data hasil uji ketuntasan belajar penguasaan konsep diperoleh $\mathrm{t}_{\text {hitung }}=4,01$. Pada taraf kesalahan 5\% dengan $\mathrm{dk}=30-1=29$ diperoleh $t_{\text {tabel }}=2,045$. Nilai $t_{\text {hitung }}>t_{\text {tabel }}$ yang berarti hasil belajar penguasaan konsep siswa telah melebihi $\mathrm{KKM}=75$ atau mencapai ketuntasan belajar. 
Lembar evaluasi penguasaan konsep yang digunakan sebanyak 35 butir soal. Peningkatan penguasaan konsep dianalisis dengan rumus $N$-Gain Normalisasi. Gain adalah selisih antara nilai pretest dan posttest. Uji gain bertujuan untuk mengetahui besar peningkatan pemahaman siswa sebelum diberi perlakuan dan setelah diberi perlakuan. Uji peningkatan rata-rata hasil belajar kognitif siswa individu maupun klasikal antara kelas eksperimen dan kelas kontrol dapat diperoleh melalui selisih antara nilai pretest dan nilai posttest.

Hasil analisis rata-rata $\mathrm{N}$-Gain penguasaan konsep adalah 0,72 dengan kategori tinggi. Dari 30 siswa, siswa yang mencapai $N$-Gain tinggi berjumlah 19 siswa, 11 siswa kategori sedang. Diketahui kriteria hasil uji gain untuk siswa nomor 1 kelas eksperimen dengan hasil pre test 26 dan post test 77 diperoleh $n$-gain sebesar 0,69 yang tergolong kriteria sedang. Sedangkan siswa nomor 1 kelas kontrol dengan hasil pre test 31 dan post test 80 diperoleh $n$-gain 0,71 yang tergolong tinggi. Secara klasikal, harga $n$-gain kelas eksperimen sebesar 0,72 tergolong dalam kriteria tinggi sedangkan $n$-gain kelas kontrol sebesar 0,69 tergolong dalam kriteria sedang. Hasil analisis klasikal kelas eksperimen dan kelas kontrol dapat dilihat pada Tabel 7 dan Gambar 2.

Tabel 7. Peningkatan N-gain kelas kontrol dan eksperimen

\begin{tabular}{lcccc}
\hline \multirow{2}{*}{ Kelas } & \multicolumn{2}{c}{ Kategori } & \multirow{2}{*}{-gain } & $\begin{array}{c}\text { Peningkatan } \\
(\boldsymbol{\%})\end{array}$ \\
\cline { 2 - 3 } & Tinggi (\%) & Sedang (\%) & & 69 \\
Kontrol & 46,47 & 53,33 & 0,69 & 72 \\
Eksperimen & 56,67 & 43,33 & 0,72 & \\
\hline
\end{tabular}

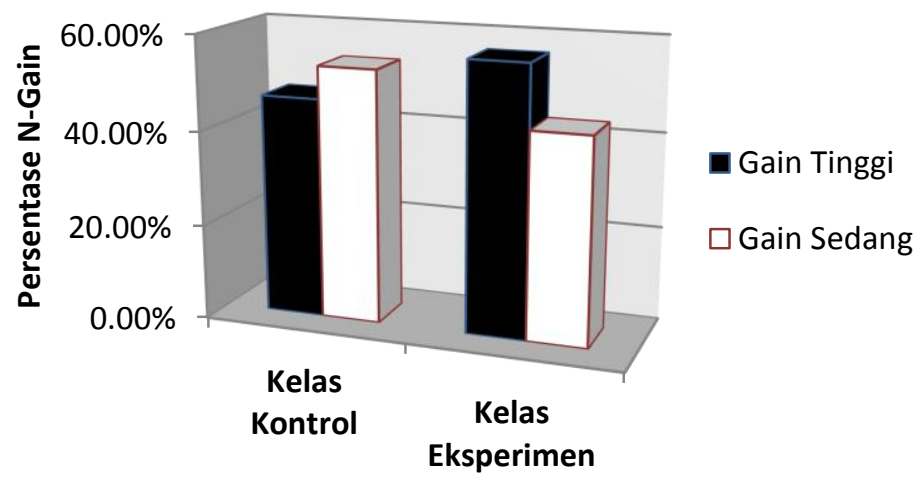

Gambar 2. Pencapaian N-gain penguasaan konsep

\section{Hasil Pengamatan Karakter (Afektif)}

Aktivitas siswa dalam pembelajaran diamati dengan menggunakan lembar pengamatan karakter. Lembar pengamatan tersebut memuat aktivitas siswa selama pembelajaran kimia dengan model project based learning. Berdasarkan hasil pengamatan selama lima kali pertemuan, secara keseluruhan karakter siswa mengalami peningkatan dengan predikat baik. Hal itu terlihat dari rata-rata skor karakter siswa dari awal pertemuan mencapai 2,07 , pertemuan kedua mencapai rata-rata 2,2, pertemuan 
ketiga mencapai rata-rata 2,52, pertemuan keempat mencapai rata-rata 2,91 dan pertemuan kelima rata-rata skor mencapai 3,11 dari skor tertinggi 4. Aktivitas siswa dalam kelas kontrol juga diamati dengan menggunakan lembar observasi yang sama dengan kelas eksperimen, hasil observasi kelas kontrol mengalami peningkatan, namun jika dibandingkan dengan hasil observasi kelas ekserimen terdapat perbedaan. Kelas eksperimen memiliki rata-rata yang lebih tinggi dibandingkan kelas kontrol. Rata-rata skor aspek karakter disajikan pada Gambar 3.

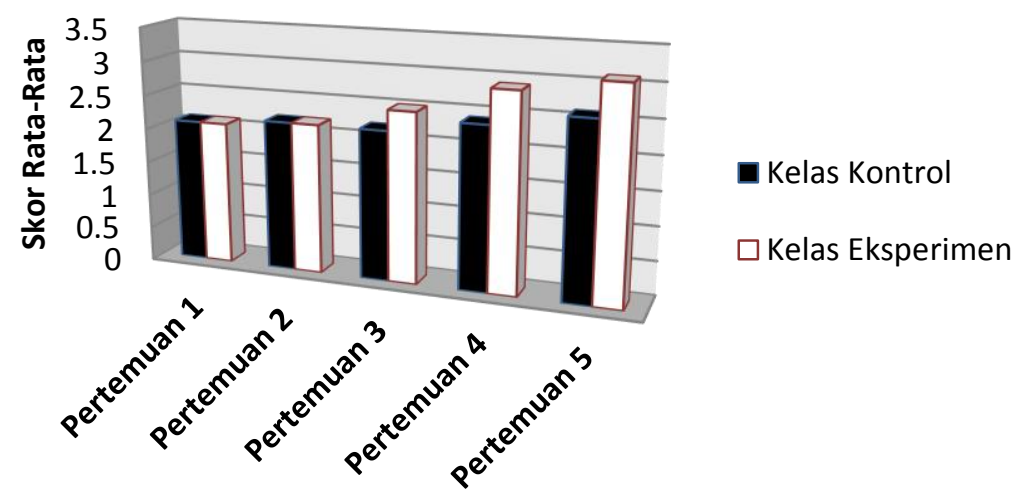

Gambar 3. Profil rata-rata aspek karakter siswa selama pembelajaran

\section{Hasil Pengamatan Proyek dan Penilaian Produk (Psikomotorik)}

Penilaian produk merupakan penilaian terhadap produk atau karya siswa yang dapat digunakan untuk menunjang keberhasilan proses pembelajaran berbasis proyek yang ada pada bahan ajar. Skor rata-rata kerja proyek siswa mencapai 70,25 dari nilai tertinggi 100 yang berarti bahwa produk yang dihasilkan dari proyek siswa rata-rata baik dengan rata-rata skor 2,81 memiliki manfaat dan layak digunakan.

\section{Respon Siswa}

Analisis deskriptif angket respon dilakukan untuk mengetahui respon siswa terhadap project based learning. Analisis persentase skor dan rata-rata tiap aspek dapat dilihat pada Tabel 8.

Tabel 8. Hasil analisis data angket respon siswa

\begin{tabular}{clccccc}
\hline No & Pernyataan & & $\begin{array}{c}\text { Persentase } \\
\text { Skor }\end{array}$ & Kriteria & $\begin{array}{c}\text { Skor Rata- } \\
\text { Rata Tiap } \\
\text { Pernyataan }\end{array}$ & Kriteria \\
\hline 1 & $\begin{array}{l}\text { Saya tertarik } \\
\text { pembelajaran kimia } \\
\text { metode proyek }\end{array}$ & $\begin{array}{l}\text { dengan } \\
\text { dengan }\end{array}$ & 98 & $\begin{array}{c}\text { Sangat } \\
\text { Baik }\end{array}$ & 3,9 & Tinggi \\
2 & $\begin{array}{l}\text { Saya tertarik } \\
\text { pembelajaran } \\
\text { menggunakan bahan ajar }\end{array}$ & $\begin{array}{c}\text { dengan } \\
\text { kimia }\end{array}$ & 78 & Baik & 3,1 & Tinggi \\
\hline
\end{tabular}




\begin{tabular}{|c|c|c|c|c|c|}
\hline 3 & $\begin{array}{lll}\text { Saya senang } & \text { dengan } \\
\text { pembelajaran kimia } & \text { dengan } \\
\text { proyek percobaan } & \end{array}$ & 83 & Baik & 3,3 & Tinggi \\
\hline 4 & $\begin{array}{l}\text { Saya merasa aktif dan ikut } \\
\text { berpartisipasi } \\
\text { pembelajaran kimia dengan } \\
\text { proyek }\end{array}$ & 87 & $\begin{array}{c}\text { Sangat } \\
\text { Baik }\end{array}$ & 3,5 & Tinggi \\
\hline 5 & $\begin{array}{l}\text { Saya lebih mudah memahami } \\
\text { materi larutan dan minyak } \\
\text { bumi dengan pembelajaran } \\
\text { proyek kimia }\end{array}$ & 87 & $\begin{array}{c}\text { Sangat } \\
\text { Baik }\end{array}$ & 3,5 & Tinggi \\
\hline 6 & $\begin{array}{l}\text { Penggunaan pembelajaran } \\
\text { kimia dengan proyek } \\
\text { mendorong saya untuk lebih } \\
\text { berinovasi memanfaatkan } \\
\text { limbah di sekitar dengan } \\
\text { berkonsep kimia }\end{array}$ & 90 & $\begin{array}{c}\text { Sangat } \\
\text { Baik }\end{array}$ & 3,6 & Tinggi \\
\hline 7 & \begin{tabular}{lrr} 
Penggunaan & \multicolumn{2}{c}{ pembelajaran } \\
kimia dengan & metode proyek \\
dapat & mengembangkan \\
kemampuan & saya & dalam \\
bekerjasama & dengan & orang \\
lain & &
\end{tabular} & 87 & $\begin{array}{c}\text { Sangat } \\
\text { Baik }\end{array}$ & 3,5 & Tinggi \\
\hline 8 & $\begin{array}{l}\text { Penggunaan pembelajaran } \\
\text { kimia dengan metode proyek } \\
\text { dapat mengembangkan } \\
\text { kemampuan saya dalam } \\
\text { memanfaatkan sumber daya } \\
\text { alam yang ada untuk membuat } \\
\text { produk - produk baru } \\
\text { berkonsep kimia }\end{array}$ & 87 & $\begin{array}{c}\text { Sangat } \\
\text { Baik }\end{array}$ & 3,5 & Tinggi \\
\hline 9 & $\begin{array}{l}\text { Penggunaan pembelajaran } \\
\text { kimia dengan proyek dapat } \\
\text { mengembangkan kemampuan } \\
\text { saya dalam memanfaatkan } \\
\text { limbah menjadi barang - } \\
\text { barang yang lebih bermanfaat }\end{array}$ & 85 & $\begin{array}{c}\text { Sangat } \\
\text { Baik }\end{array}$ & 3,4 & Tinggi \\
\hline 10 & $\begin{array}{l}\text { Penggunaan pembelajaran } \\
\text { kimia dengan proyek } \\
\text { membuat saya ingin lebih } \\
\text { mendalami } \\
\text { limbah dalam kemanfaatan } \\
\text { sehari-hari. }\end{array}$ & 87 & $\begin{array}{c}\text { Sangat } \\
\text { Baik }\end{array}$ & 3,5 & Tinggi \\
\hline 11 & $\begin{array}{lr}\text { Pembelajaran } & \text { proyek } \\
\text { membuat saya lebih } \\
\text { bersemangat menerapkan } \\
\text { konsep kimia untuk mengatasi } \\
\text { masalah di lingkungan sekitar }\end{array}$ & 88 & $\begin{array}{c}\text { Sangat } \\
\text { Baik }\end{array}$ & 3,5 & Tinggi \\
\hline 12 & $\begin{array}{l}\text { Saya ingin pada setiap } \\
\text { pembelajaran kimia diselingi } \\
\text { dengan pembelajaran proyek }\end{array}$ & 87 & $\begin{array}{c}\text { Sangat } \\
\text { Baik }\end{array}$ & 3,5 & Tinggi \\
\hline
\end{tabular}


Profil respon siswa terhadap pembelajaran materi larutan dengan project based learning dapat dilihat pada Gambar 4, sedangkan hasil analisis rata-rata skor tiap aspek ditunjukkan pada Gambar 5.

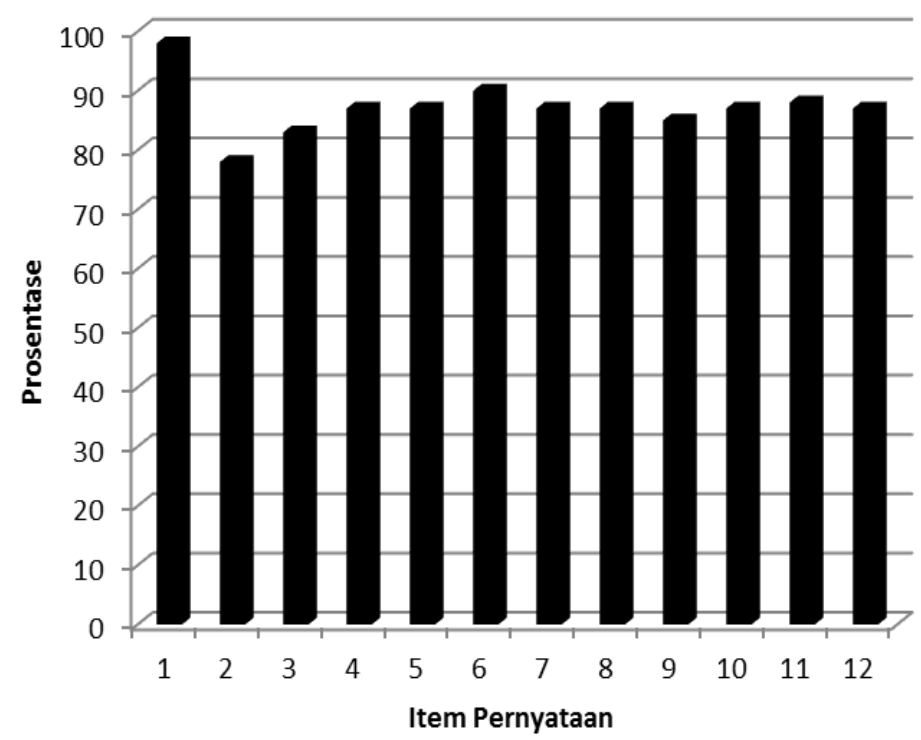

Gambar 4. Analisis persentase angket respon pembelajaran

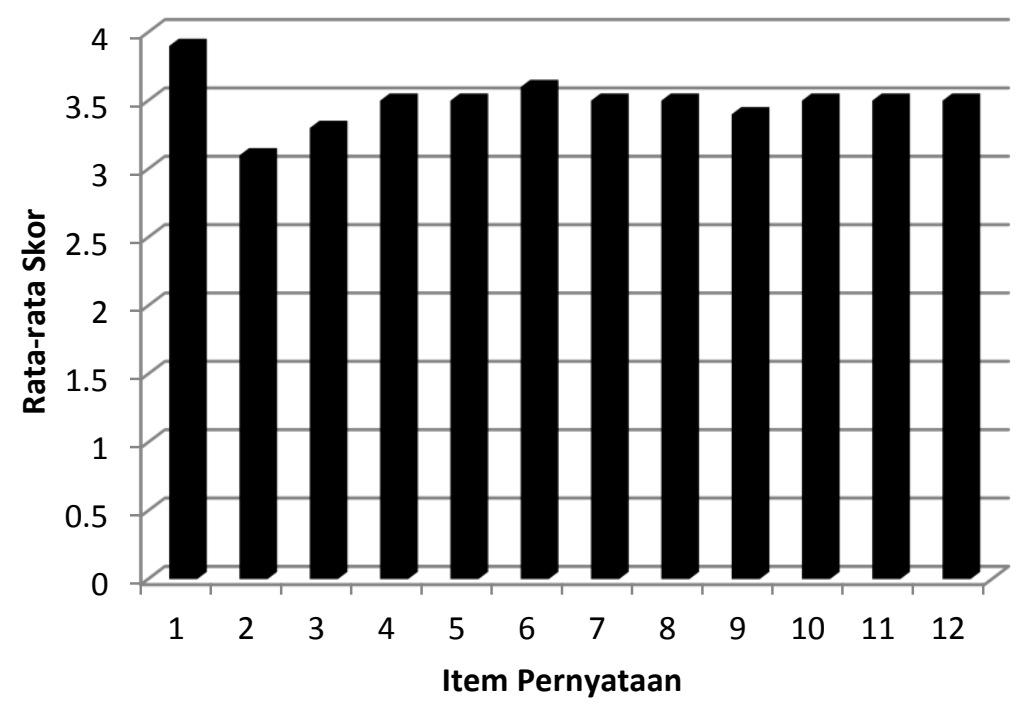

Gambar 5. Grafik rata-rata skor tiap pernyataan angket respon pembelajaran 
Data respon siswa terhadap project based learning menunjukkan bahwa pada umumnya siswa memberikan respon positif terhadap kegiatan pembelajaran yang telah dilaksanakan. Hal ini ditunjukkan dari 30 siswa memberikan pernyataan yang positif dengan kriteria baik dan sangat baik. Data tersebut jika dikonfirmasikan dengan kriteria maka diperoleh kesimpulan bahwa siswa memberikan respon positif terhadap pembelajaran yang diterapkan.

\section{Tahap Refleksi (See)}

Daryanto \& Arisandi (2015) menyampaikan bahwa "Aktivitas peserta didik dari awal hingga akhir pembelajaran pada umumnya cukup baik, tidak terganggu dengan kehadiran observer, sehingga kelas terlihat sangat hidup". Hal ini benar-benar terbukti, secara umum observer memberikan tanggapan bahwa keaktifan, kemandirian dan karakter siswa dari pertemuan awal hingga pertemuan akhir semakin meningkat. Sangat berbeda dengan keadaan kelas pada saat awal pertemuan, siswa terlihat begitu canggung dalam pembelajaran, pertemuan kedua siswa masih kebingungan dalam pencarian literatur, namun dengan masukan para observer pertemuan selanjutnya siswa dipersilahkan mencari bahan/literatur yang akan digunakan untuk proyek dengan memanfaatkan fasilitas dari sekolah sepulang jam belajar. Seiring berjalannya waktu siswa tampak lebih nyaman, semangat dan dapat mengikuti pembelajaran dengan baik bahkan hasil observasi yang didapat dari para observer terdapat peningkatan karakter siswa pada kelas eksperimen dibandingkan dengan kelas kontrol.

\section{SIMPULAN}

Penerapan pembelajaran project based learning dengan menggunakan sarana lesson study di kelas eksperimen memberikan hasil lebih baik dibandingkan dengan siswa kelas kontrol yang menerapkan pembelajaran dengan metode ceramah dan diskusi yang juga sama dengan menggunakan sarana lesson study. Pembelajaran project based learning mendapatkan respon positif dari seluruh siswa.

\section{DAFTAR RUJUKAN}

Creswell, J. W. (2014). Research Design Pendekatan Kualitatif, Kuantitatif, dan Mixed. Yogyakarta: Pustaka Pelajar.

Daryanto. \& Arisandi, Y. (2015). Program Induksi untuk Guru Pemula. Yogyakarta: Gava Media.

Sanjaya, W. (2013). Strategi Pembelajaran Berorientasi Standar Proses Pendidikan. Jakarta: Kencana Prenadamedia Group.

Sugiyono. (2015). Metode Penelitian Pendidikan Pendekatan Kuantitatif, Kualitatif, dan $R \& D$. Bandung: Alfabeta. 